\title{
THE USE OF TREATED BLEACHED KRAFT PULP MILL EFFLUENT ON EUCALYPTUS PLANTATION
}

\author{
Ana Augusta Passos Rezende \\ Federal University of Ouro Preto, Brazil \\ Antonio Teixeira de Matos \\ Cláudio Mudado Silva \\ Julio César Neves \\ Federal University of de Viçosa, Brazil
}

\begin{abstract}
The use of treated pulp mill effluent on eucalyptus plantation appears to be an attractive option for plant nutrition and water supply. It also constitutes a supplementary treatment process or final disposal option for the mill effluent. This study aimed at the investigation and evaluation of the effects of bleached kraft pulp mill treated effluent (BKME) on three typical Brazilian soils used for Eucalyptus plantation. The BKME was characterized and five different application rates, defined according to the load of sodium, were tested in controlled environment experiments (greenhouse). After BKME application over a six month period an expressive increase in the salinity of the studied soils was observed, although no dispersal effects in soil with high clay content were detected. The low content of some nutrients in the BKME, indicated the need for complementation in fertirrigation. In general, the best biomass productivity and plant growth results were obtained in fine textured soil at a loading rate of $6.49 \mathrm{t}$ sodium.ha-1. In general, the good response of the soil-plant system under different effluent application rates showed the possibility of agricultural use of BKME if adequate management practices and monitoring are conducted.
\end{abstract}

\section{KEYWORDS}

Eucalyptus nutrition, land disposal, pulp mill effluent, wastewater.

\section{INTRODUCTION}

The pulp industry is among those that have been considering and using land application as an alternative for disposing its wastewaters. Pulp mills generate large volumes of effluent with different characteristics, depending upon the type of industrial process used. Land application becomes an attractive altemative to existing disposal systems because it reduces the effluent load to surface water and works as a source of water and nutrient for cultivated areas.

The first experience on effluent land application in the pulp industry occurred in North America, during the 1950 's, mainly in experimental or pilot forestation projects $[1,2]$. In the 1980 's, land application technique was limited to few mills and employed only in nonforested areas. Literature also reported some studies aimed at application of pulp mill effluents as an option of water closed-cycle in the forest industry [3, 4]. 
An important concern related to pulp mill effluent Land Application refers to the accumulation of salts in the soil, as a result of long period application [5].

This paper evaluated the agronomic and environmental implications of using a bleached kraft pulp mill treated effluent (BKME) on Eucalyptus plantation in Brazil, through trickle irrigation technique (dripping). The effects of this application on soil characteristics, on plant nutrition, growth and on biomass production were evaluated.

\section{METHODOLOGY}

The experiment was carried out in controlled environment greenhouse. The experiment was comprised of 90 lab soil columns containing samples of three typical Brazilian soils: clayey Typic Kandiudults, sandy Typic Kandiudults and Typic Quartzipsamments. Eucalyptus seedlings of hybrid of E. grandis x E. Urophyla were planted in each column. Each soil column was submitted, over a six month period, to five different BKME application rates in daily dripping applications $\left(0 ; 114.6 ; 286.5 ; 515.7\right.$ and $\left.1146 \mathrm{~mm}_{\text {year }}{ }^{-1}\right)$, corresponding to the following sodium application loads: $0 ; 0,85 ; 2,12 ; 3,80$ and $8,50 \mathrm{t} \mathrm{ha}^{-1}$ year $^{-1}$. In 45 experimental columns, it was also simulated the occurrence of a rainy season after the ninetieth day of cultivation. It was simulated an annual medium precipitation of $1300 \mathrm{~mm}$, typical of the studied region.

The BKME used in the experiment was originated from an aerated lagoon treatment system of a Brazilian pulp mill. Table 1 shows the physical-chemical characteristics of the effluent.

The clayey Typic Kandiudults and sandy Typic Kandiudults (PAd1 and PAd2 soils) used in the experiment, have characteristically a sandy superficial horizon (A) and a subsurface horizon (B) with yellowish color and medium to loamy texture that reduces the permeability. These soils are of low natural fertility, possessing low cation exchange capacity and are poor in iron and in exchangeable bases.

The Typic Quartzipsamments (RQo soil) are characterized as a sandy soil with a slight increase in the clay percentage as the profile depth increases. This is excessively drained soil, with quick permeability all along the profile, predominantly acid, with low base saturation and low organic material and nutrient contents. Table 2 shows the chemical characteristics of the studied soils.

The following parameters were monitored during the six month period: ambient temperature, the evapotranspiration water volume, the application rates of simulated rain, the physical and chemical characteristics of the water drained from the columns, the visual symptoms of deficiency or toxicity in the plants, as well as the morphological characteristics (size and stem diameter) of the plants. At the end of this period, physical and chemical analyses of the soils were conducted in samples collected in five different depths of each column, as well the chemical analysis of the foliar material of the eucalyptus plants. Analytical methodology was adopted according to EMBRAPA [6] and APHA [7]. Data were interpreted through variance and regression analysis. 
Kalmar ECO-TECH 07

KALMAR, SWEDEN, November 26-28, 2007

Table 1: Characterization of the secondary treated pulp mill effluent

\begin{tabular}{|c|c|c|}
\hline Parameters & Unit & Avarege Value \\
\hline Colour & $\mathrm{mg} \mathrm{L}^{-1}$ de $\mathrm{Pt}$ & 1369 \\
\hline $\mathrm{pH}$ & - & 7,58 \\
\hline Total Solids (TS) & $\mathrm{mg} \mathrm{L}^{-1}$ & 2446 \\
\hline Total dissolved solids (TDS) & $\mathrm{mg} \mathrm{L}^{-1}$ & 1789 \\
\hline Suspended solids (SS) & $\mathrm{mg} \mathrm{L}^{-1}$ & 60,0 \\
\hline Decantable solids sedimentáveis & $\mathrm{mL} \cdot \mathrm{L}^{-1}$ & 0,25 \\
\hline $\mathrm{COD}^{3}$ & $\mathrm{mg} \mathrm{L}^{-1}$ & 375 \\
\hline $\mathrm{BOD}^{4}$ & $\mathrm{mg} \mathrm{L}^{-1}$ & 68 \\
\hline $\mathrm{EC}^{5}$ & $\mathrm{dS} \mathrm{m}^{-1}$ & 3,4 \\
\hline Sodium ( $\mathrm{Na}$ ) & $\mathrm{mg} \mathrm{L}^{-1}$ & 742 \\
\hline Calcium (Ca) & $\mathrm{mg} \mathrm{L}^{-1}$ & 49 \\
\hline Magnesium (Mg) & $\mathrm{mg} \mathrm{L}^{-1}$ & 77 \\
\hline $\mathrm{SAR}^{6}$ & - & 26,2 \\
\hline Kjeldhal Nitrogen & $\mathrm{mg} \mathrm{L}^{-1}$ & 6,8 \\
\hline Ammonium & $\mathrm{mg} \mathrm{L}^{-1}$ & 1,69 \\
\hline Nitrate & $\mathrm{mg} \mathrm{L}^{-1}$ & 0,00 \\
\hline Phosphorus (P) & $\mathrm{mg} \mathrm{L}^{-1}$ & 1,07 \\
\hline Potassium (K) & $\mathrm{mg} \mathrm{L}^{-1}$ & 27,4 \\
\hline Sulfur (S) & $\mathrm{mg} \mathrm{L}^{-1}$ & 116,65 \\
\hline Copper $(\mathrm{Cu})$ & $\mathrm{mg} \mathrm{L}^{-1}$ & 0,01 \\
\hline iron $(\mathrm{Fe})$ & $\mathrm{mg} \mathrm{L}^{-1}$ & 0,57 \\
\hline $\operatorname{Zinc}(\mathrm{Zn})$ & $\mathrm{mg} \mathrm{L}^{-1}$ & 0,05 \\
\hline Manganese (Mn) & $\mathrm{mg} \mathrm{L}^{-1}$ & 0,31 \\
\hline Aluminum (Al) & $\mathrm{mg} \mathrm{L}^{-1}$ & 3,45 \\
\hline Boron (B) & $\mathrm{mg} \mathrm{L}^{-1}$ & 0,17 \\
\hline Cadmium $(\mathrm{Cd})$ & $\mathrm{mg} \mathrm{L}^{-1}$ & 0,001 \\
\hline Cobalt (Co) & $\mathrm{mg} \mathrm{L}^{-1}$ & 0,005 \\
\hline Chromium $(\mathrm{Cr})$ & $\mathrm{mg} \mathrm{L}^{-1}$ & 0,135 \\
\hline Mercury $(\mathrm{Hg})$ & $\mathrm{mg} \mathrm{L}^{-1}$ & 0,016 \\
\hline Molybdenum (Mo) & $\mathrm{mg} \mathrm{L}^{-1}$ & 0,029 \\
\hline Nickel (Ni) & $\mathrm{mg} \mathrm{L}^{-1}$ & 0,016 \\
\hline Lead $(\mathrm{Pb})$ & $\mathrm{mg} \mathrm{L}^{-1}$ & 0,027 \\
\hline Silicium (Si) & $\mathrm{mg} \mathrm{L}^{-1}$ & 5,00 \\
\hline Vanadium (V) & $\mathrm{mg} \mathrm{L}^{-1}$ & 0,009 \\
\hline Chloride $\left(\mathrm{Cl}^{-}\right)$ & $\mathrm{mg} \mathrm{L}^{-1}$ & 493 \\
\hline Carbonate & $\mathrm{mg} \mathrm{L}^{-1}$ de $\mathrm{CaCO}_{3}$ & 0 \\
\hline Bicarbonate & $\mathrm{mol}_{\mathrm{c}} \mathrm{L}^{-1}$ de $\mathrm{CaCO}_{3}$ & 8,3 \\
\hline $\mathrm{AOX}^{2}$ & $\mathrm{mg} \mathrm{L}^{-1} \mathrm{de} \mathrm{Cl}^{-}$ & 4,59 \\
\hline Total Coliform & $\mathrm{NMP} / 100 \mathrm{~mL}$ & $<5000$ \\
\hline Fecal Coliform & $\mathrm{NMP} / 100 \mathrm{~mL}$ & $<1000$ \\
\hline
\end{tabular}

1. average of monthly values 2. Adsorbable Organic Halogens 3. Chemical Oxygen Demand 4. Biochemical Oxygen Demand 5. Electric Conductivity 6. Sodium Adsorption Ratio, given by $\mathrm{SAR}=\mathrm{Na}^{+}\left(\mathrm{Ca}^{+2}+\mathrm{Mg}^{+2}\right)^{-1 / 2}$, where $\mathrm{Na}^{+}, \mathrm{Ca}^{+2} \mathrm{e} \mathrm{Mg}^{+2}$ are expressed in $\mathrm{cmol}_{\mathrm{c}} \mathrm{L}^{-1}$. 
Table 2: Soils chemical characteristics"

\begin{tabular}{|c|c|c|c|c|c|c|c|c|c|c|c|}
\hline \multirow{2}{*}{ Soil ${ }^{2}$} & \multirow{2}{*}{$\begin{array}{l}\text { Deph } \\
(\mathrm{cm})\end{array}$} & \multirow{2}{*}{$\begin{array}{c}\mathrm{pH} \\
\mathrm{H}_{2} \mathrm{O}\end{array}$} & $\mathrm{P}$ & & $\mathrm{Na}$ & $\mathrm{Ca}^{2+}$ & $\mathrm{Mg}^{2+}$ & $\mathrm{Al}^{3+}$ & CTC & \multirow[t]{2}{*}{ CTC } & \multirow{2}{*}{$\begin{array}{c}\mathrm{V} \\
\%\end{array}$} \\
\hline & & & \multicolumn{4}{|c|}{$\mathrm{mg} \mathrm{dm}$} & \multicolumn{3}{|c|}{$\mathrm{cmol}_{\mathrm{c}} \mathrm{dm}^{-3}$} & & \\
\hline \multirow{3}{*}{ PAdl } & $0-10$ & 4,67 & 19,06 & 16 & 10 & 0,48 & 0,19 & $0, \overline{72}$ & 1,47 & 6,23 & 12,0 \\
\hline & $10-60$ & 4,79 & 3,20 & 10 & 11 & 0,71 & 0,20 & 0,72 & 1,71 & 5,68 & 17,4 \\
\hline & $60-100$ & 4,59 & 0,56 & 9 & 7 & 0,15 & 0,06 & 0,96 & 1,22 & 3,43 & 7,6 \\
\hline \multirow{3}{*}{ PAd2 } & $0-10$ & 4,79 & 4,86 & 9 & 10,0 & 0,20 & 0,11 & 0,36 & 0,73 & 3,01 & 12,3 \\
\hline & $10-60$ & 4,90 & 0,86 & 4 & 6,0 & 0,27 & 0,16 & 0,24 & 0,71 & 2,78 & 16,9 \\
\hline & $60-100$ & 4,88 & 0,47 & 8 & 6,0 & 0,41 & 0,11 & 0.36 & 0,93 & 3,01 & 18,9 \\
\hline \multirow{3}{*}{ RQo } & $0-30$ & 5,51 & 4,75 & 6 & 4,0 & 0,65 & 0,23 & 0,00 & 0,92 & 2,7 & 34,1 \\
\hline & $30-60$ & 5,59 & 0,78 & 1 & 2,0 & 0,18 & 0,04 & 0,00 & 0,23 & 0,56 & 41,1 \\
\hline & $60-100$ & 5,50 & 1,12 & 1 & 2,0 & 0,17 & 0,05 & 0,00 & 0,23 & 0,82 & 28 \\
\hline
\end{tabular}

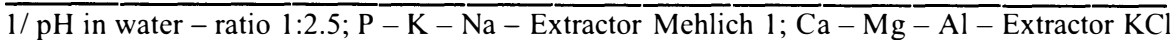
1 moleL $^{-1} ; \mathrm{CTC}(\mathrm{t})$ - Effective cation exchange capacity; CTC (T) - Cation exchange capacity at $\mathrm{pH}$ 7.0; V - base saturation index. 2/ PAd1-Dystrophic Yellow Clayey Typic Kandiudult, medium/clayey texture; PAd2- Dystrophic Yellow Sandy Typic Kandiudult, sandy/medium texture; RQo-Typic Quartzipsamment, sandy texture.

\section{RESULTS AND DISCUSSION}

\subsection{Effects of BKME application on soil physical and chemical properties}

According to the effluent characteristics presented in Table 1 and the usual irrigation water quality criteria [ 8 - 12], it can be observed that the exchangeable sodium constitutes an important limitation factor for the effluent use in agricultural cultures. Concentration of sodium in the effluent varied from 450 to $1000 \mathrm{mg} \mathrm{L}^{-1}$, with an average of $750 \mathrm{mg} \mathrm{L}^{-1}$. Sodium concentration up to $70 \mathrm{mg} \mathrm{L}^{-1}$ may present some restriction for spray irrigation use; it could present toxicity problems for plants [13].

After BKME application over a six month period an expressive increase in the conductivity or salinity of the studied soils, especially at high BKME application rates, was observed. However, no significant clay dispersion effects in soil with high clay content were noted. Although the high sodium concentration and the relatively low calcium (28 to $110 \mathrm{mg} \mathrm{L}^{-1}$ ) and magnesium ( 4 to $11 \mathrm{mg} \mathrm{L}^{-1}$ ) concentration resulting on a high sodium adsorption ratio (SAR), it seems that the high electric conductivity (EC) minimized the effects of clay dispersion during effluent application.

Elevated values of EC, exchangeable sodium, and chloride ions were obtained in the superficial layers $(0-40 \mathrm{~cm})$ of the soil columns. There was a significant variation on sodium concentration in the soil profiles. A less expressive effect was observed in the soil of sandy texture (RQo). The adjusted regression equations in function of BKME application rates, for different depths, are indicative of different behaviors from each soil, in terms to the exchangeable sodium concentration (see Table 3). The medium/clayey texture soil (PAd1) presented a tendency for quadratic variation in the sodium concentration with the effluent 
application rate, while the sandy/medium texture soils (PAd2) and the sandy soil (RQo) presented a linear increase in the concentration of sodium with the effluent application rates along the soil profile.

Table 3. Effect of effluent application ratio on concentration of exchangeable sodium along the soil profile

\begin{tabular}{|c|c|c|c|}
\hline Soil & Deph $(\mathrm{cm})$ & Adjusted Equations & $\mathrm{R}^{2}$ \\
\hline PAd1 & $0-10$ & $\hat{\mathrm{y}}=49,955+0,3307^{* *} \mathrm{x}+0,00142^{* *} \mathrm{x}^{2}-0,1165 \mathrm{E}-05^{* *} \mathrm{x}^{3}$ & 0,891 \\
\cline { 2 - 4 } & $10-20$ & $\hat{\mathrm{y}}=8,784+0,77947^{* *} \mathrm{x}-0,00038^{* *} \mathrm{x}^{2}$ & 0,848 \\
\cline { 2 - 4 } & $20-30$ & $\hat{\mathrm{y}}=10,049+0,3402^{* *} \mathrm{x}-0,000136^{\circ} \mathrm{x}^{2}$ & 0,817 \\
\cline { 2 - 4 } & $30-40$ & $\hat{\mathrm{y}}=3,625+0,1062^{* *} \mathrm{x}$ & 0,901 \\
\cline { 2 - 4 } & $40-55$ & $\hat{\mathrm{y}}=5,654+0,0588^{*} \mathrm{x}$ & 0,619 \\
\hline PAD2 & $0-10$ & $\hat{\mathrm{y}}=21,2+6,5821^{*} \mathrm{x}^{0.5}+0,1149^{* *} \mathrm{x}$ & - \\
\cline { 2 - 4 } & $10-20$ & $\hat{\mathrm{y}}=40,1+0,3829^{* *} \mathrm{x}$ & 0,909 \\
\cline { 2 - 4 } & $20-30$ & $\hat{\mathrm{y}}=28,341+0,2869^{* *} \mathrm{x}$ & 0,966 \\
\cline { 2 - 4 } & $30-40$ & $\hat{\mathrm{y}}=16,9633+0,1519^{* *} \mathrm{x}$ & 0,721 \\
\cline { 2 - 4 } & $40-55$ & $\hat{\mathrm{y}}=5,9521+0,09825^{* *} \mathrm{x}$ & 0,852 \\
\hline RQo & $0-10$ & $\hat{\mathrm{y}}=22,862+0,1093^{* *} \mathrm{x}$ & 0,858 \\
\cline { 2 - 4 } & $10-20$ & $\hat{\mathrm{y}}=14,499+0,1037^{* *} \mathrm{x}$ & 0,779 \\
\cline { 2 - 4 } & $20-30$ & $\hat{\mathrm{y}}=18,597+0,1147^{* *} \mathrm{x}$ & 0,968 \\
\cline { 2 - 4 } & $30-40$ & $\hat{\mathrm{y}}=14,928+0,09615^{* *} \mathrm{x}$ & \\
\cline { 2 - 4 } & $40-55$ & $\hat{\mathrm{y}}=-0,762+0,2623^{* *} \mathrm{x}$ & \\
\hline
\end{tabular}

$* *,{ }^{*},{ }^{\circ}$ : significant coefficient to $1 \%, 5 \%$ and $10 \%$, respectively.

$\hat{\mathrm{y}}=$ estimated sodium concentration. PAdl-Dystrophic Yellow Clayey Typic Kandiudult, medium/clayey texture; PAd2- Dystrophic Yellow Sandy Typic Kandiudult, sandy/medium texture; RQo-Typic Quartzipsamment, sandy texture.

The rain simulation in the experiment provided a reduction of the electric conductivity values in the entire soil profiles. It demonstrates that, in rainy periods, the risk for soil salinity due to the BKME application can be reduced. This is probably due to the leaching of exchangeable sodium

It is expected that other methods could facilitate the sodium transport in the soil profile, such as the application with other sources of $\mathrm{Ca}^{+2}$ and $\mathrm{Mg}^{+2}$ which together with the high rainy level can control the soil electric conductivity

The high drainage level of the sandy soil (RQo) avoided severe salinity effects and permeability reduction during effluent application, as also reported in other studies [14 - 16]. Based on these results, it is assumed that the application of BKME in sandy texture soils, or in soils with artificial drainage systems, can provide a good control of soil sodicity.

The metal concentrations in BKME are below the permissible values for release in surface water in Brazil [17], and do not constitute a limitation factor for effluent application on soils. There was no significant variation in the concentration of $\mathrm{Cu}, \mathrm{Cr}, \mathrm{Pb}$ and $\mathrm{Ni}$ in the studied soils. The higher BKME application rate did not increase the content of $\mathrm{Cd}, \mathrm{Cr}, \mathrm{Ni}$ and $\mathrm{Pb}$ up to the maximum values suggested by the European Economical Community, mentioned by 
Loehr [18], Simon \& Tedesco [19] and also adopted in the State of Paraná, Brazil [20] for land application.

The concentration of chlorinated organic material in BKME, measured by the concentration of AOX (Adsorbable Organic Halogen) was around $4,5 \mathrm{mg} \mathrm{Cl}^{-} \mathrm{L}^{-1}$. The AOX concentration in the effluent is dependable on the pulp bleaching sequence and the amount of chlorinated compounds used. The AOX concentration observed in this study is considered very low because of the bleaching process used in the mill. Nevertheless, as discussed by Kookana and Rogers [21], those remaining AOX in the effluent should be retained physically and degraded in the soil first layers. This was observed in the experiment by analysis of the physical and chemical characteristics of the water drained from the columns, except for the sandy texture soil (Quartzipsammen soil).

\subsection{Effects of the BKME application on the plants}

After a six month period of BKME application some effects on the Eucalyptus plants related to the biomass production and the growth characteristics of the plants were observed. There was a tendency of an increase in plant height, log diameter, dry matter of the aerial part, and dry matter of root with the increment of the BKME application rate. It was also observed a satisfactory tolerance of the eucalyptus plants to the effluent application in the soil.

In general, the best biomass productivity and plant growth were obtained in medium/clayey textur soil (Padl) at a BKME application rate of $880 \mathrm{~mm}$, corresponding to a loading rate of $6.5 \mathrm{t} \mathrm{Na} \cdot \mathrm{ha}^{-1}$. The lowest growth rate and biomass production were observed for the sandy soil (RQo). Plant growth and biomass production varied linearly with the BKME application rates in the sandy/medium textured soil, and thus the best results were obtained at the highest rate (1146 mm) (see Figure 1).

Relating to the plant nutrition aspect, in general, the concentrations found in the soils that received the BKME application were compatible with reference values for Eucalyptus fertilization. It was observed the largest growth and biomass production to the soil columns that received the largest rates of BKME application, due to the largest macro and micronutrients contained in BKME, in spite of the larger accumulation of sodium in the soil.

It was not observed any reduction on water consumption neither an increase in the hydraulic stress by the growing plants with the increase of the effluent application rate. However, there was no evidence of the salinity effect on the plant growth and biomass production. 
Soil PAd 1 - SC

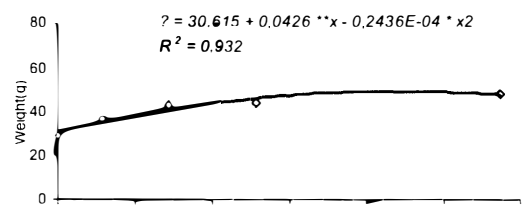

Soil PAd2 - SC
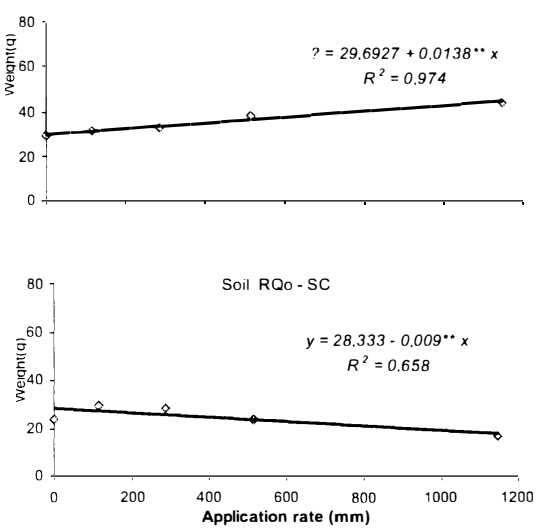

Soll PAd 1 - CC

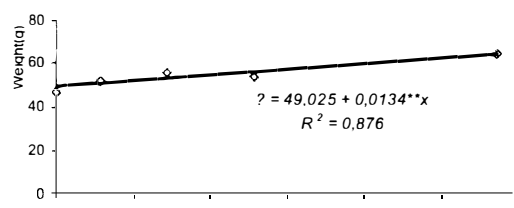

Soil PAd2 - CC
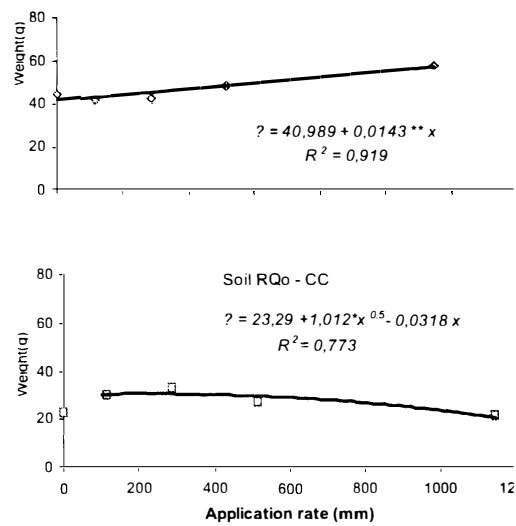

SC - only effluent application; CC - effluent application with rain simulation $* *, *,{ }^{\circ}$ : significant coefficient to $1 \%, 5 \%$ and $10 \%$, respectively

Figure 1. Dry matter of the aerial part of Eucalyptus plants in the soils PAd1, PAd2 and RQ。 at the end of a six month period of BKME application.

A global analysis of all experiments showed that during simulated rain testing there was a significant improvement in the height, dry matter of the aerial part and dry matter of root of the plants (see Table 3).

The relationship of leaves/fine roots $(\mathrm{w} / \mathrm{w})$ decreased during rain simulation trials. This indicates that the washout and drainage of the leachate provides a minimization of the salinization effects on soils. The results also indicated that removal of the salt accumulated in the root zone would be necessary to minimize the negative effects on water supply and plant toxicity. Intermittent effluent application, intercalated with periods of non-saline water application (rain or irrigation), should make it possible to remove great amounts of salt, especially in the sandy soil. In general, the good response of the soil-plant system under different effluent application rates confirms the possibility of agricultural use of BKME. 
Table 3 - Average " of the stem diameter, the height, dry matter of the aerial part and dry matter of root of the Eucaliptus plants, for the different soils under different experiment conditions (without and with rain simulation), including all BKME application rates.

\begin{tabular}{|c|c|c|c|c|}
\hline \multirow{2}{*}{ Parameter } & \multirow{2}{*}{ Experiment $^{2}$} & \multicolumn{3}{|c|}{ Soil } \\
\hline & & PAdd & PAd2 & $\mathrm{RQ}_{\mathrm{w}}$ \\
\hline \multirow[t]{2}{*}{ Diameter $(\mathrm{cm})$} & SC & $0,87 \mathrm{Ba}$ & $0,85 \mathrm{~A} \mathrm{a}$ & $0,68 \mathrm{Ab}$ \\
\hline & $\mathrm{CC}$ & $0,94 \mathrm{Aa}$ & $0,86 \mathrm{Ab}$ & $0.66 \mathrm{Ac}$ \\
\hline \multirow{2}{*}{ Height $\quad(\mathrm{cm})$} & $\mathrm{SC}$ & $76,58 \mathrm{Bab}$ & $77.70 \mathrm{Ba}$ & $65.71 \mathrm{Ab}$ \\
\hline & $\mathrm{CC}$ & $88,64 \mathrm{~A} \mathrm{a}$ & $89,10 \mathrm{~A} \mathrm{a}$ & $63.31 \mathrm{Ab}$ \\
\hline \multirow{2}{*}{ Dry matter of the aerial part $(\mathrm{g})$} & $\mathrm{SC}$ & $40,04 \mathrm{Ba}$ & $35.38 \mathrm{~B} \mathrm{~b}$ & $24,62 \mathrm{Ac}$ \\
\hline & $\mathrm{CC}$ & $54.55 \mathrm{~A} \mathrm{a}$ & $46,91 \mathrm{Ab}$ & $27.21 \mathrm{Ac}$ \\
\hline \multirow[t]{2}{*}{ Dry matter of the root $(\mathrm{g})$} & $\mathrm{SC}$ & $13,50 \mathrm{Ba}$ & $16,68 \mathrm{Ba}$ & $17.03 \mathrm{~A} \mathrm{a}$ \\
\hline & $\mathrm{CC}$ & $19,48 \mathrm{~A} \mathrm{a}$ & $21,79 \mathrm{~A} \mathrm{a}$ & $19,09 \mathrm{~A} \mathrm{a}$ \\
\hline
\end{tabular}

1/The average value followed by at least the same capital letter in the columns and lower case letter in the lines, for each soil does not differ in 5\% of probability by Tukey test. $2 / \mathrm{SC}-$ only BKME application; CC- BKME application and rain simulation.

\section{CONCLUSIONS}

The relatively good behavior of the soil-plant system, when submitted to different effluent application rates, confirmed the possibility of agricultural use of the treated pulp kraft mill effluent (BKME) on Eucalyptus plantation.

The present research work allowed to move forward in the viability study of the application of treated pulp kraft mill effluent (BKME) on eucalyptus plantation in a way to guarantee its sustainable use, according to its importance in the current Brazilian scenery: tendency to the shortage of water resources, large volume of effluent generated in the production of pulp, extensive eucalyptus planting areas near to the mills, great water and nutrient plant demand, and constant need of improvement of the environmental acting of the pulp producers.

The information obtained in this study gave information for a better understanding of the behavior of BKME, when applied in eucalyptus plantations in Typic Kandiudults and Quartzipsamments soils, contributing for establishing safe management conditions in agreement with the assimilation capacity of the soil-plant system.

For the selection of the BKME application rate to the soil, the sodium concentration should be taken as the main limitation factor. The characteristics of each soil should be considered in the definition of application rates and that the alternating effluent application with non saline water application (rain or irrigation) should make possible the removal of great amount of salts, especially in sandy soils. 


\section{REFERENCES}

[1] Crawford, S.C., 1958. Spray irrigation of certain sulfate pulp mill wastes. Sewage Industrial and Wastes, 30(20), 2306 - 2309.

[2] Westenhouse, R., 1960. Irrigation Disposal of Wastes. Tappi, NC, 46 (8), 160- 165

[3] Smith, C.T.; Carnus, H; Wang, G.; Stuthridge, T. and Tomer, M., 1997. Land application of CTMP effluent in New Zealand: from research to practice. In: Proceedings of Third International Conference on Environmental Fate and Efıects of Pulp and Paper Mill Effluents, CSIRO, Rotoura, New Zealand.

[4] Thacker, W.E.,1985. Silvicultural Land Application of Wastewater and Sludge from the Pulp and Paper Industry. In: The Forest Alternative for Treatment and Municipal Utilization of Wastes, University of Washington Press, Washington A.D. pp. 41-54.

[5] Fuller, W.H., Warrick, A.W., 1985. Soils in Waste Treatment and Utilization. CRC Press, Mouth Raton, Florida.

[6] Embrapa - Brazilian Agricultural Research Company, 1997. Manual of Soil Analysis. EMBRAPA, Rio de Janeiro, Brasil. (in Portuguese)

[7] APHA. American Public Health Association/American Water Works Association/Water Environment Federation, 1997. Standard Methods for the Examination of Water and Wastewater, 20th ed, Washington DC, USA.

[8] Ayers, R.S., Westcot, D.W., 1991. The Quality of the Water in the Agriculture. UFPB, Campina Grande, Brazil.

[9] USEPA-US Environmental Protection Agency, 1981. Process Manual Design for Land Treatment of Municipal Wastewater. EPA, Technology Transfer, Cincinnati. EPA 625/181-013.

[10] UNEP - United Nations Environment Program, Industry \& Environment Office, 1996. Environmental management in the pulp and paper industry. UNEP, France. Technical Report 34.

[11] USEPA-US Environmental Protection Agency, 1992. Guidelines for water reuse. Washington, DC. Technical Report EPA/625/R-92/004.

[12] OMS - Organización Mundial de La Salud, 1989. Diretrices sanitarias sobre el uso de aguas residuales en agricultura y acuicultura. Informações Técnicas 78.OMS, Ginebra.

[13] Feigin, A.; Ravina, I., Shalhevet, J., 1991. Irrigation with Treated Sewage Effluent: Management goes Environmental Protection. Springer-Verlag. Berlin.

[14] Cromer, R.N., Tompkins, D., Barr, N. J., Hopmans, P., 1994. Irrigation of Monterey Pine with Wastewater: effect on soil chemistry and groundwater composition. Journal Environmental Quality, Madison, WI, 13 (4), 539 -542.

[15] Johnson, B., Ryder, I., 1988. The Disposal of Pulp and Paper Mill Effluents by Spray Irrigation onto Farmland. In: Alternative Waste Treatment Systems, Bhamidimarri, ed., pp. $55-65$.

[16] Juwarkar, A.S., Subrahmanyam, P.V.R., 1986. Impact of Pulp and Paper Mill Wastewater on Crop and Soil. Water Science Technology, Great Britain, 19, 693-700.

[17] CONAMA. National Council of the Environment (Brazil), 2005. Resolution $n^{\circ} 357$. Official Diary of the República Federativa of Brazil. (in Portuguese)

[18] Loehr, R.A., 1984. Pollution Control goes Agriculture. Academic Press Inc., New York.

[19] Simon, Z., Tedesco, M.J., 1993. A broad view on semi-liquid waste treatment on agricultural soils. In: Proceedings of $17^{\circ}$ Brazilian Congress of Sanitary and Environment Engineering, ABES, Natal, Brazil. (in Portuguese)

[20] SANEPAR. Parana State Sanitation Company, 1997. Sludge application on agriculture in Paraná State, Brazil. Technical Manual. Sanepar, Curitiba, Brazil. (in Portuguese) 
Kalmar ECO-TECH '07

KALMAR, SWEDEN, November 26-28, 2007

[21] Kookana, R.S., Rogers, S.L., 1995. Effects of Pulp Mill Effluent Disposal on Soil. Reviews of Environmental Contamination and Toxicology, New York, 142, 13 - 64.

470 